Article

\title{
Determination of Electricity Demand by Personal Light Electric Vehicles (PLEVs): An Example of e-Motor Scooters in the Context of Large City Management in Poland
}

\author{
Anna Brdulak 1,*(D), Grażyna Chaberek ${ }^{2} \mathbb{D}$ and Jacek Jagodziński ${ }^{3}$ \\ 1 Faculty of Computer Science and Management, Wrocław University of Science and Technology, \\ 50-370 Wrocław, Poland \\ 2 Faculty of Oceanography and Geography, University of Gdańsk, 80-309 Gdynia, Poland; \\ grazyna.chaberek@ug.edu.pl \\ 3 Faculty of Electronics, Wrocław University of Science and Technology, 50-370 Wrocław, Poland; \\ jacek.jagodzinski@pwr.edu.pl \\ * Correspondence: anna.brdulak@pwr.edu.pl
}

Received: 28 October 2019; Accepted: 27 December 2019; Published: 1 January 2020

\begin{abstract}
Personal light electric vehicles (PLEVs) are a phenomenon that can currently be observed in cities, intended to be an ecological form of transport. The authors of the paper make an attempt to determine electricity consumption by PLEVs in the context of managing a large city in accordance with the concept of sustainable development. The article is of a cognitive nature. Research questions posed against the background of the goal formulated are as follows: how strong will the demand for PLEVs be (in the example of e-motor scooters, taking into consideration the number of vehicles) and for the electricity consumed by PLEVs. The method used is a simulation model. The conducted analyses demonstrate that a dynamic growth of PLEVs will result in an increased energy demand, which must be taken into account by the cities, developing according to the sustainable development conception.
\end{abstract}

Keywords: personal light mobility vehicle; PLEV; city management; smart city; simulation model; strategy; sustainable development; green energy; e-motor scooter

\section{Introduction}

According to UN-Habitat, cities generate $70 \%$ of the global GDP, consume $60 \%$ of energy and produce $70 \%$ of waste [1]. It is estimated that by $2030,75 \%$ of the world's energy will be consumed by cities [2]. In this paper, the authors focus on the issue of energy consumption by the city in the context of its development in accordance with the sustainable development principles. Given the scale of energy consumption by the cities in a global perspective, one of the fundamental challenges that the city authorities face is the reduction of energy consumption. In this context, more and more widespread shared mobility should be mentioned, which is gaining popularity in large cities.

The new, separate category of urban mobility provides for sharing different types of vehicles, such as bicycles, scooters, motor scooters, or cars. The popularity of the shared mobility concept may result both from a change in consumer behaviour, a shift away from ownership, and a greater emphasis on accessibility [3], and from attempts to counteract the increasing environmental pollution in cities and excessive energy consumption.

Shared mobility entails dynamic growth of personal light electric vehicles (PLEVs). According to the definition by the Light Electric Vehicle Association (LEVA), PLEVs are electric, light, battery, 
fuel cell, or hybrid-powered two- or three-wheeled vehicles weighing less than $100 \mathrm{~kg}$. The most popular vehicles in this group include electric bikes, scooters, and e-motor scooters [4].

It can be concluded from the survey Transport-Sharing in Poland [5], conducted by the global technology consultancy DataArt, that at the end of 2018, transport-sharing offered 18.3 thousand cars, motor scooters, bicycles, and scooters. Traditional bicycles (11.9 thousand) account for the largest group of PLEVs. They are available in six of the seven largest cities. The largest network operates in Warsaw, where 5.8 thousand bicycles are available. The second largest group are cars (3.8 thousand). Warsaw is also the leader here, with 1.6 thousand cars rented by four suppliers. All groups include 2.6 thousand vehicles altogether (14\% of all vehicles) driven exclusively by electricity. The largest part is made up of electric motor scooters with a rapidly growing number of electric scooters [5]. Hence, the authors will focus their analyses on e-motor scooters.

During the analysis of the above phenomenon, a question arises about the future impact of it on increasing the urban energy consumption. A simulation model can be used to estimate the amount of energy that will be required to power PLEVs (specifically e-motor scooters). There are several models related to energy consumption forecasting in the literature that have been extensively described and analysed [6-9]. Yet, it seems that the sharing of the selected PLEV means of transport, the e-motor scooter, has not been examined in detail yet.

Considering the above, the purpose of this article is to make an attempt to determine the amount of electricity consumption in the context of the dynamic development of the PLEV market. The article is of a cognitive nature. The authors will use a simulation model.

The research questions posed in the article, which the authors seek to find answers to, are as follows:

Q1: how strong will the demand for e-motor scooters be (considering the number of vehicles)?

Q2: how strong will the demand for electricity necessary to power e-motor scooters be?

Q3: what is the level of the expected energy demand for e-motor scooters compared to the electricity consumption by other means of transport in Polish cities (for the purposes of the analysis a daily energy consumption by the Warsaw metro was compared)?

\section{Materials and Methods}

\subsection{State of Art}

In order to identify a research gap and systematize available knowledge, the authors conducted an analysis of available scientific publications in the thematic area of this article. In the Web of Science Core Collection, taking into consideration a range from 1950 up to now, there were found 411 results. All of them referred to the subject of electric scooters, including e-scooters. In particular, the above topics concerned the subject of accidents and health effects of crashes and injuries, technical aspects related to performance, or applications for sharing systems in cities.

Hardt and Bogenberger [10] wrote about the issue of e-motor scooters in the urban environment, while issues related to urban logistics were addressed by the Italian authors Nocerino, Colorni and Lia [11]. Issues about the role of early adopters in technology diffusion can be found also in Seebauer's article [12] entitled "Why early adopters engage in interpersonal diffusion of technological innovations: An empirical study on electric bicycles and electric scooters".

The authors, looking through scientific databases, also searched for publications based on keywords. There were no articles found with a keyword "PLEV" (in both Web of Science and Scopus databases), while "personal light electric vehicle" brought 37 results in Web of Science and 119 in Scopus. Among these groups of publications, it could be distinguished as those referring to the crash and injuries $[13,14]$, smart mobility $[15,16]$, as well as smart mobility and reduction in climate influence of transportation $[17,18]$.

A total of 15 results in Web of Science database were obtained through a detailed analysis of the available scientific publications and a combination of the keywords "smart city" AND "electric energy consumption". The publications found relate to the combination of smart city and electric 
vehicles [19-21]. In addition to the publications mentioned above, two thematic areas, electric transportation [22-24] and topics related to energy consumption in general [25], have been distinguished. It is worth emphasizing that the key word "e-motor scooter" did not bring any results, while a combination of "electric scooter" AND "energy consumption" resulted in five scientific publications concerning the better performance and efficiency of e-scooters.

Going further, as the next step in the analysis of scientific publications, all databases in EBSCOhost were searched. The use of "electric scooter" AND "energy consumption" keywords in particular gave a total 24 results, including the subject areas connected with sustainable transport, zero emission, and climate, as well as sustainable transport strategy for promoting zero-emission electric scooters in Taiwan [26]. The problem of energy efficiency of hydrogen fuel cell scooters is presented also by Hwang and Chang [27] in their joint publication in International Journal of Hydrogen Energy. Bishop et al. [28] presents a slightly different perspective on the above issues, conducting a broad analysis of the technical, economic, and environmental performance of electric vehicles, based on the examples of electric scooters. Also, Walker and Holger [29] undertook the analysis of costs and energy consumption in the context of hybrid electric powertrain configurations for two-wheelers. When two keywords, "smart city" AND "electric energy consumption", were combined, six results were obtained, including only two for electric vehicles.

Analyzing the number of publications in the EMERALD database that relate to the subject of the article, searching by using two keywords together "electric scooter" AND "energy consumption", 52 publications were received. Most of them referred to the topic of ecological urban transport, the impact of transport on the environment, as well as environment-friendly supply chains, and smart cities.

Based on the above analysis, it could be concluded that the subject of electricity consumption by PLEVs, in particular e-motor scooters, has a research potential, what was noticed and used by the authors of the article.

\subsection{Choice of Bass Diffusion Model}

The formal basis for the forecast of energy consumption by e-motor scooters presented in this article is the innovation diffusion model proposed by Bass. It should be noted that in order to be able to use the proposed solution, an e-motor scooter should be regarded as a product innovation as defined by OECD [30]. A strong assumption was therefore made that an e-motor scooter in a set of different electric vehicles is characterized by significant differences compared to other devices of this type. The implication that this assumption has not been fulfilled may be the sharing of the market of e-motor scooters and, for example, other vehicles with similar properties (electric short-range vehicles). What is more, a product innovation means that a user of another PLEV (like a self-balancing unicycle or hoverboard) is ready to buy (use) also an e-motor scooter as a separate solution available on the market. The main objection against this approach may be that vehicles such as motor scooters, e-motor scooters, skateboards, e-skateboards, hoverboards, and e-unicycles are often part of the so-called category wheeled recreational devices [31]. This means that they serve a single purpose and formally replace a single solution. Owing to significant technological differences they will be used by different types of users. For example, the manufacturer of Segway e-unicycles explicitly points out that certain skills are required to use the model: "riders with a certain skill set, combined with a fearless mindset, can learn to ride in about an hour" [32].

E-motor scooters, which do not require an additional skill set from their users, are a separate type of vehicle. In addition, the solution making it possible to rent e-scooters within a city is in itself an innovation in terms of the new service. This is a meaningful application of these vehicles. OECD defines a business process innovation which comprises this use of e-motor scooters.

In this study, a decision was made to use one of the innovation diffusion models for forecasting. This approach is based on an analogy between the spread of a new, previously unknown service or product and the physical process of diffusion. In Polish literature, Kot et al. proposed the following division [33]: 
- a deterministic model-in the form of differential equations: the Hudson model, where the increase in the number of innovation users is proportional to the current number of opponents; the Mansfield model, based on the dynamics underlying the epidemic theories; the Davies model, taking into account differences between the profitability of individual companies in the innovation process; or the Bass model, taking into consideration innovators and imitators;

- a stochastic model—based on the probability theory, where most often particular states are defined (supporter and opponent of a given innovation);

- a wave model—with innovation spreading in time and space.

The diffusion model was chosen arbitrarily, based on the existing data and on the fact that deterministic models provide precise forecasts. On the other hand, stochastic and wave models require a different set of information that is more difficult to assess, even though they can be transformed into a one-dimensional diffusion equation. A detailed overview of mathematical (deterministic) models describing the accumulation of adoptions can be found in paper [34]. However, the best known and most frequently quoted model is the one proposed by Bass [35]. This model is often used alongside the so-called logistic and Gompertz projections, while ordinary predictions based on the Bass model are the most pessimistic [36]. This is an additional argument in favour of this model. An additional significant aspect is the duality of the model with the Rogers model. In his work, Rogers proposed specific names for particular groups of technology users [37]. Therefore, the Bass model, together with Rogers' interpretation, has a significant role to play in the evaluation of innovation.

In order to better illustrate the proceedings in modeling taken by the authors, the sequence of individual stages is presented below (Figure 1).

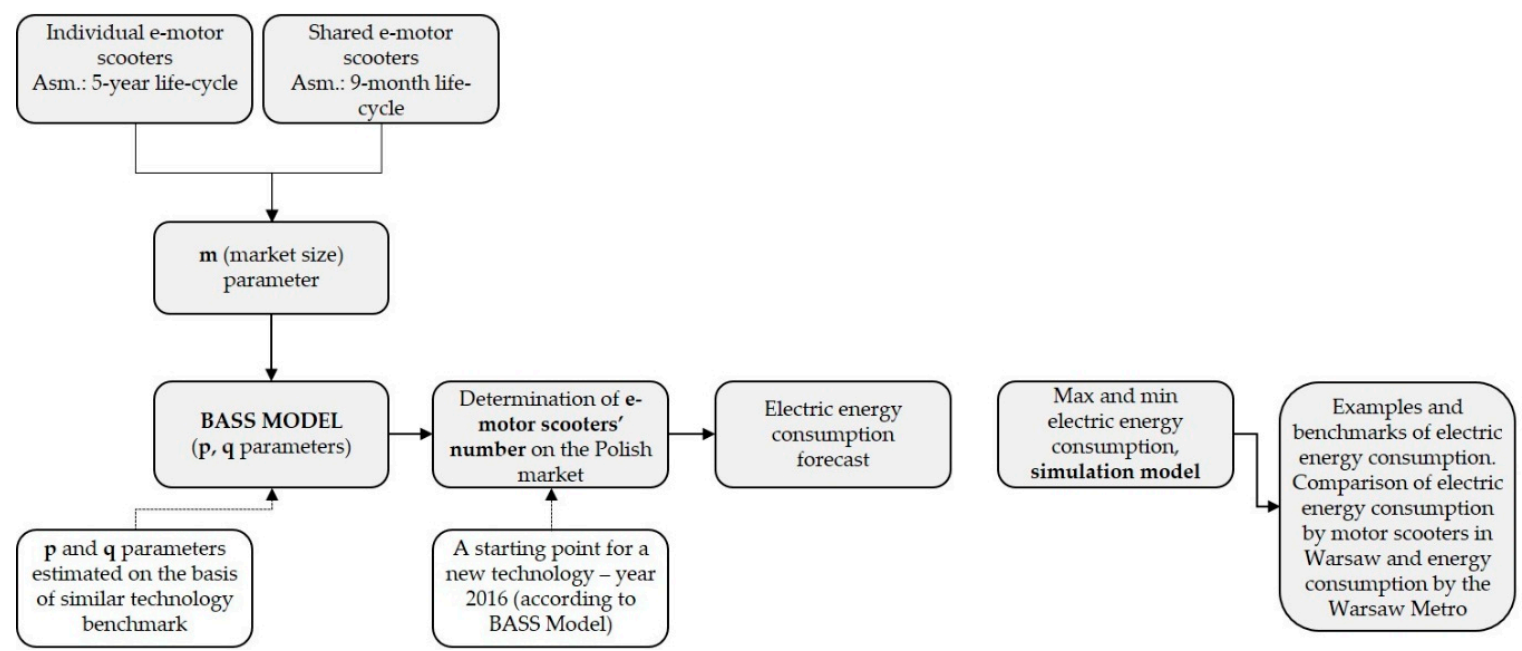

Figure 1. Subsequent stages of the proceedings [own elaboration].

The total market size (parameter $\mathrm{m}$ ) comprises individual e-motor scooters and shared e-motor scooters. It is used in Bass model, on which the forecast of e-motor scooters on the Polish market was based. The carried-out analysis allows determination of the size of electric energy consumption and, going further, construction of the simulation model. In order to better illustrate the amount of electricity consumed by e-motor scooters and to emphasize the importance of this fact for the city, the amount of electricity consumed by the e-motor scooters has been compared with the electric energy consumption of the Warsaw Metro. 


\section{Results}

\subsection{Estimation of Bass Model Parameters}

Below you will find the method of selecting parameters for the Bass model (Appendix A). The first key parameter is $\mathrm{m}$-the size of the Polish target market. It is obvious that e-motor scooters as a technology are likely to be adopted only by users with specific characteristics. In our opinion, these will be two groups of users. The first of them are enterprises providing e-motor scooter services in cities with a mobile phone application. The second group consists of individual users who among other available PLEV products choose this particular type of technology.

In order to assess the number of e-motor scooters that can serve cities, international markets that already have such vehicles should be looked at. According to the Bass model, these vehicles are used by end-user groups.

The American market and a city which has a population similar to that of major Polish cities, i.e., less than one million, have been chosen for analysis. The difficulty in obtaining information about the number of e-motor scooters in a given city should be emphasized. This is due to the fact that service providers do not publish general statistics. According to Cnet.com [38], which analysed all the service providers with subsidiaries in San Francisco, there are about 2350 e-motor scooters in a city with 883,305 inhabitants [39]. Thus, it can be easily calculated that there is 1 vehicle per 400 inhabitants.

An assumption has been made that in Poland this service has a chance of success in cities with a population of more than 50,000 people. According to the World Population Review, there are 61 such cities [40] in Poland, which gives an estimated number of 29,900 e-motor scooters for rental. It is assumed that there is one e-motor scooter per 400 inhabitants (rounded down with an accuracy of 50). The results are presented in Table 1.

However, it should be noted that there are some deviations from the assumptions made. Owners of electric motor scooters sometimes decide to enter smaller markets with special tourist attractions. An example is Wieliczka (20,000 inhabitants), where e-motor scooters were made available on 20 August 2019. The city currently has 20 vehicles [41].

Individual customers are the second group of users. In this case, it is assumed that an appropriate infrastructure must be available to use such a vehicle. This is due to the fact that the vehicle is not suitable for uneven terrain. Therefore, large cities with better access to infrastructure are the first-choice option. Thus, it was agreed that the vehicles described above will be used primarily by city dwellers.

According to the Statistics Poland [43] data (as of 31 December 2018), Polish cities are inhabited by 23,067,244 people. Assuming that one per mile of the aforementioned group will use the technology, we get nearly 23,000 users. Hence, the total target market amounts to $\mathrm{m}=29,500+23,000=52,500$. In the literature a separate analysis for buying and renting [44] is sometimes made for electric vehicles, but this study focuses only on buying. This is related to the fact that energy consumption is to a larger extent linked to the lifecycle of the vehicle than to the rental market.

In order to make a prediction using the Bass model, an innovation coefficient $p$ and imitation coefficient $q$ for a given technology should be known. Such parameters can be selected on the basis of the history of market adoption of another similar technology. Examples of such a selection, based on the properties of the curve and the method of the smallest squares, can be found in the works $[45,46]$. The authors encountered some difficulty in trying to assess the number of vehicles because there was no information on this subject in Polish statistical yearbooks. The only data that could be acquired were the general sales information that failed to demonstrate the full adoption of the technology. 
Table 1. Estimated number of e-scooters in Polish cities with a population of more than 50,000 [own study based data from: Statistics Poland (GUS) Demographic Yearbook of Poland, 2017 [42]].

\begin{tabular}{cccccc}
\hline Name & Population & $\begin{array}{c}\text { Estimated } \\
\text { Number of } \\
\text { e-Scooters }\end{array}$ & Name & Population & $\begin{array}{c}\text { Estimated } \\
\text { Number of } \\
\text { e-Scooters }\end{array}$ \\
\hline Warsaw & $1,764,615$ & 4400 & Elblag & 120,895 & 300 \\
Krakow & 767,348 & 1900 & Plock & 120,787 & 300 \\
Łodz & 690,422 & 1700 & Walbrzych & 113,621 & 250 \\
Wroclaw & 638,586 & 1550 & Wlocławek & 111,752 & 250 \\
Poznan & 538,633 & 1300 & Tarnow & 109,650 & 250 \\
Gdansk & 464,254 & 1150 & Chorzow & 109,021 & 250 \\
Szczecin & 403,883 & 1000 & Koszalin & 107,670 & 250 \\
Bydgoszcz & 352,313 & 850 & Kalisz & 101,625 & 250 \\
Lublin & 339,850 & 800 & Legnica & 100,324 & 250 \\
Bialystok & 297,288 & 700 & Grudziadz & 95,629 & 200 \\
Katowice & 296,262 & 700 & Jaworzno & 92,090 & 200 \\
Gdynia & 246,306 & 600 & Slupsk & 91,465 & 200 \\
Czestochowa & 224,376 & 550 & Jastrzebie-Zdroj & 89,590 & 200 \\
Radom & 214,566 & 500 & Nowy Sacz & 84,041 & 200 \\
Sosnowiec & 204,013 & 500 & Jelenia Gora & 80,072 & 200 \\
Torun & 202,562 & 500 & Siedlce & 77,653 & 150 \\
Kielce & 196,804 & 450 & Konin & 74,834 & 150 \\
Rzeszow & 189,662 & 450 & Myslowice & 74,647 & 150 \\
Gliwice & 181,309 & 450 & Piotrkow Trybunalski & 74,312 & 150 \\
Zabrze & 174,349 & 400 & Suwalki & 69,554 & 150 \\
Olsztyn & 173,070 & 400 & Siemianowice Slaskie & 67,523 & 150 \\
Bielsko-Biala & 171,505 & 400 & Zamosc & 64,354 & 150 \\
Bytom & 168,394 & 400 & Leszno & 64,197 & 150 \\
Zielona Gora & 139,819 & 300 & Chelm & 63,333 & 150 \\
Rybnik & 139,129 & 300 & Lomza & 63,092 & 150 \\
Ruda Slaska & 138,578 & 300 & Zory & 62,243 & 150 \\
Tychy & 128,211 & 300 & Przemysl & 61,808 & 150 \\
Opole & 128,140 & 300 & Biala Podlaska & 57,545 & 100 \\
Gorzow Wielkopolski & 124,295 & 300 & Piekary Slaskie & 55,652 & 100 \\
Dabrowa Gornicza & 121,121 & 300 & Ostrołeka & 52,215 & 100 \\
& & Swietochlowice & 50,385 & 100 \\
\hline & & & Total: & 29,500 \\
\hline
\end{tabular}

However, it should be stressed that sales data, the number of users and e-scooters are distinct parameters, highly dependent on the lifetime of the product. It is assumed that the owner of e-motor scooter technology in the city will keep the fleet at a steady level. Therefore, if the product's lifetime comes to an end, the user will buy a new one. This assumption is not included in the original Bass model and should be considered in the case of sales forecasts. However, in this study the presented analysis shows only the market penetration for number of e-scooters, which is definitely different from the number of users, due to the type of service-rentals.

In estimating the parameters of the Bass model, the most similar technology and the impact of the region should be taken into account. Because the data on the number of e-scooters for another area are not available, it was decided to take other vehicles using alternative energy sources for analysis. The data from the United States due to high adoption level of this technology type were arbitrarily selected. Parameters $p$ and $q$ for electric vehicles are listed in the works $[47,48]$. For the U.S. various vantage points are taken into account, thus: diffusion for vehicles using alternative fuels (AFV) $p=0.09312^{*}$ and $q=0.4692^{*}$ [49] (parameters estimated based on monthly data were annualized by multiplication with factor 12), PHEV $p=0.0026 ; q=0.709$ [48], EV $p=0.00303 ; q=0.6331$, hybrid $p=0.02, q=0.3$ [44]. The authors did not have the original sources of parameters in all cases - data provided indirectly according to the sources indicated (see Appendix C).

The area where diffusion occurs was taken into consideration. To specify the value of imitation and adoption parameters for Polish users, data from other technologies adopted in the country have been used. The work [47] provides estimated parameters for Poland $p=0.0109$ and $q=1.0497$ 
(broadband internet technology). Similarly, in the work [50] parameters for ICT (information and communication technology) were estimated $-p=0.0013, q=0.503$, indicating a relatively low level of innovation coefficient and a relatively high imitation index $q$ for Poland (world average for $q=0.38$ [51]). The work [52] demonstrates that Poland has the highest imitation index compared to the neighbouring countries owing to a very specific Polish market; it is also worth noting that parameter $q>1$ is not treated as an inadequate value for the model, and can be interpreted as an additional impact on the desire to duplicate technology. In addition, the innovation and imitation coefficients for Poland were calculated using the algorithm presented by [53], where $p=0.0293$ and $q=0.863$ (Appendix B).

Based on the European Alternative Fuels Observatory data on the total number of alternative fuels from passenger cars [54], the coefficients of the Bass model were estimated using the least squares method: $p=0.0000307, q=0.34299$ (Appendix C). This is the example of the development of a similar innovation in a wider area, including Poland. For comparison, the diffusion forecast of Toyota hybrids in the European Union is the innovation coefficient $p=0.0008$, and imitation coefficient $q=0.2318$ [48].

Figure 2 presents a scatter plot of available $\mathrm{p}$ and $\mathrm{q}$ values. The figure shows the calculated mean for the imitation and innovation coefficient $p=0.0191, q=0.5630$. These are the factors selected for the final forecast. Figure 2 shows also the average for the region of Poland and the European Union marked as mean (EU and PL) and for technology marked as mean (US), which the present study is considered as the confidence intervals for the parameters $p$ and $q . \quad p \in[0.0085,0.0297]$, $q \in[0.5278,0.5981]$. The presented approach results from the fact that only some of the selected coefficients from the literature have a calculated standard error.

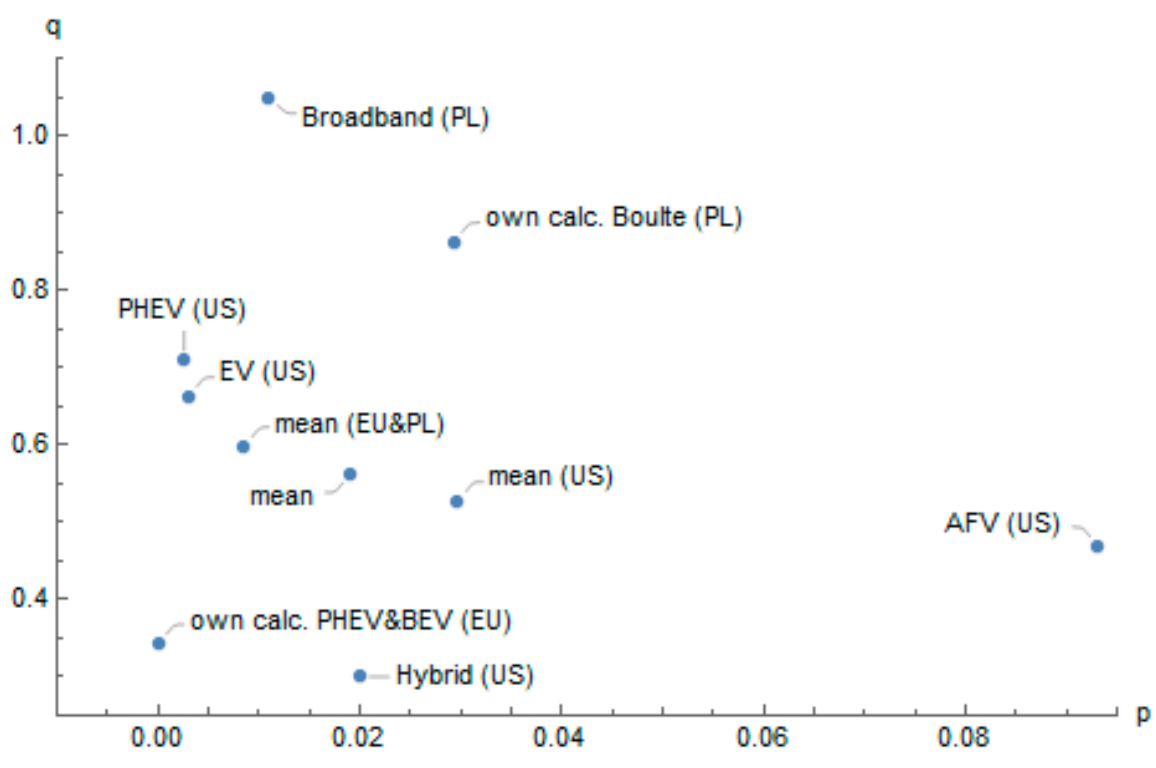

Figure 2. Scatter plot of available $p$ and $q$ values [own elaboration].

July 2016 was taken as the starting point for the technology. It means that the innovation in the form of e-motor scooters already existed in Poland before this date. However, it was adopted only by innovators accounting for less than $p=2 \%$ of the target market (according to the Rogers model). The starting point was taken on the basis of calculations. Since the number of e-motor scooters for Poland in January 2019 was about 5000 according to the study [55], under the adopted model diffusion should start about 2.471 years earlier, i.e., around July 2016 (details in Appendix D).

The diagram of the Bass model is shown in Figure $3 a$ and the cumulative S-curve in Figure $3 \mathrm{~b}$.

The presented forecast is based on the Bass model. It should be noted that the adopted approach is described in the literature as a forecasting by analogy (FBA). In such context, the application of other diffusion models, such as the logistic model or Gompertz model, could be limited by data availability. In the paper the process of selecting $p$ and $q$ parameters for the specific model is presented. 
Variables are selected on the basis of the technology type and the diffusion area. For the technology studied, the available data is not sufficient to obtain a satisfactory forecast. There are no time series regarding the sales of this technology on the Polish market. Considering the broader class of vehicles, including electric vehicles, data for Poland seem to be not sufficient enough to construct the model. Therefore, in Appendix $C$ the attempt of such a forecast for the EU as a whole is presented. However, without assumptions about the market size-endogenous potential, the Bass model brings insufficient results. Nevertheless, once the market size assumption is made, the differences between the Bass and Gompertz models are negligible.

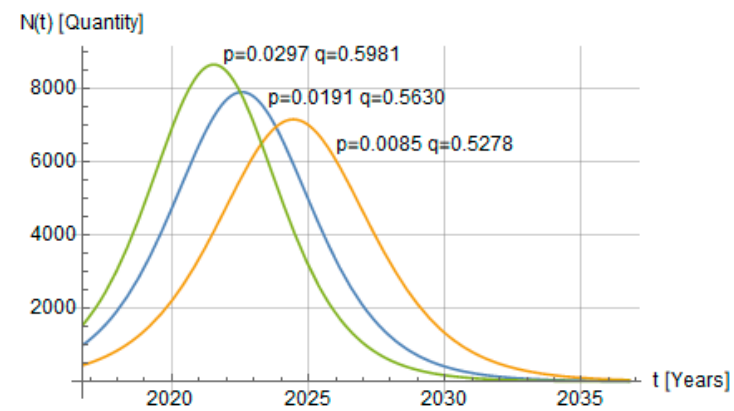

(a)

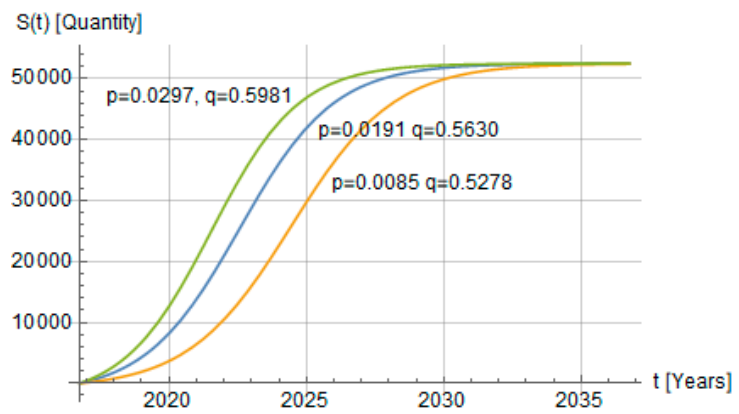

(b)

Figure 3. Prediction according to the Bass model for e-motor scooters: (a) current values; (b) cumulative values [own elaboration].

\subsection{Electricity Consumption}

For sales forecasts, the product lifecycle related to the battery life of e-scooters as defined in [56] was assumed. It should be pointed out that the e-motor scooter, which operates as a rented device in the city, is intensively used and, according to the analyses of the vehicle owners themselves, can be used from six months to two years. One and a half years was assumed for the purposes of the model.

As a result, after this period the owner buys a new e-motor scooter in order to be able to keep the fleet at the base level. For individual users, it is assumed that a vehicle that is used economically can last for up to five years.

The question that arises concerns the impact of the growing number of vehicles on the level of electricity consumption in the city. Against the background of considerations on the impact of selected PLEV means of transport, the sales data for bicycles not powered by electricity should be quoted here. Their sales continue to grow, reaching 1.2 million units in $2016[57,58]$. This may indicate that the popularity of electric vehicles in Poland is increasing, but it is still far from high.

In the next four years, it could be noticed that e-motor scooters appear to be a good alternative to petrol-powered motor scooters. The e-motor scooter currently consumes an average of about $4 \mathrm{kWh}$ (kilowatt hours) per $100 \mathrm{~km}$ [59]. The number was confirmed with the experts, the CEO of an e-motor scooter rental company. It should be mentioned that the authors are aware of limitation of the usage of single study, however there was a problem with the lack of available data observed. Despite the undertaken trial's need to possess indispensable data, the e-motor scooters rental companies refused to share any information. Having in mind the restrictions described above, the authors made an effort to estimate the quantity of energy consumed by PLEVs on the basis of a single, but reliable study.

According to an interview with an expert, the CEO of one of the companies renting e-motor scooters in Wroclaw and Legnica, it can be determined that the average speed of the e-motor scooter in the city is $30 \mathrm{~km} / \mathrm{h}$ and the average rental lasts for $10-15 \mathrm{~min}$. Therefore, we obtain the average distance of 3-4 km per usage. According to the CEO, in a high season (May-September) there are about ten rentals per day. For further consideration it can be assumed that the average daily rental for all months of use (March-November) is seven. Therefore, the number of kilometres driven per e-motor scooter per day amounts to 28. Under the above assumptions, the amount of energy consumed per day per 
e-motor scooter equals $1.12 \mathrm{kWh}$. When calculating the energy consumption for the whole year of e-motor scooters in use, we must take into account their lifetime $(9$ months $=275$ days, from March till November), sales forecast in four years (30,000 units), and the amount of daily energy consumption $(1.12 \mathrm{khW})$. Then, the average energy consumption per day per all e-motor scooters present on the Polish market should be about 33.6 MWh. It means, that during a year, the cities will need 9.24 GWh to power their e-motor scooters.

As a result of the analysis, the following answers to research questions were found out:

A1 (Q1): expected demand for e-motor scooters using the Bass model will reach 30,000 vehicles in Poland in a four-year time, that is in 2023;

A2 (Q2): with this predicted number of e-motor scooters expected amount of daily energy consumption will be $1.12 \mathrm{khW}$ and during a year, the cities will need $9.24 \mathrm{GWh}$ to power their e-motor scooters;

A3 (Q3): for comparison, the annual electricity demand of the Warsaw Metro for Lines M1 and M2 in 2018 amounted to approximately $125 \mathrm{GWh}(+/-10 \%)$. The average energy consumption of the Warsaw Metro for per working day in the summer months is estimated at 369 MWh level [60].

The predicted amount of energy seems to be high despite the authors being aware of the large error margin in these estimates. Not all the data could be obtained during research because the e-motor scooters and e-scooters have appeared in the cities only recently on a noticeable scale. There are still few studies that could result from research into this phenomenon. This concerns especially Polish cities, where the use of PLEVs has attracted interest since more of these vehicles have appeared and become a kind of nuisance. In April 2019, over 3000 personal transport devices were already in use in Poland, and the demand for them has been growing since [61]. The presented model allows for the analysis of various scenarios of the development of the studied phenomenon. It does not have to contain all the data for the reasoning to be correct.

\section{Discussion}

The presented model is an approximate simulation of the demand for electricity in the cities as a result of the changing mobile behaviour of the city dwellers, mainly owing to the emergence of new devices making it possible to move around faster. The purpose of the model was to illustrate certain trends that may differ with the changing demographic, market, technological, and, above all, political and legal conditions. The model, along with better and better knowledge of the phenomenon in Polish cities, will be supplemented and developed.

The two key scenarios that will affect the performance of the model are the upward trend and the downward trend.

The scale and trends of the phenomenon in the longer term will be determined mainly by the demographic factor, i.e., the total number of inhabitants, and the demographic trend. The number of PLEV users will be more affected by the number of inhabitants living in the city than in the suburban area. It may be argued that the percentage of trips using PLEVs in the cities will depend mainly on the percentage of pedestrians and commuters using public transport, with the assumption that motor scooters/bikes/scooters are more willingly used by pedestrians and public transport users than by people using cars [62]. This is mainly due to the fact that PLEVs, because of their range and speed, mainly replace walking or communication between public transport access points. Therefore, the main area where these devices can be used will be city centres, where the journeys are short, chiefly on foot or by public transport, which is confirmed by data on mobility in large Polish cities [63].

The second important underlying factor affecting the number of PLEV users will be the general trend related to the use of cars in urban travel. Based on traffic surveys in large cities, a downward trend in the dependence of households on cars can be observed. For example, in Wroclaw (the fourth largest city in Poland), the number of cars per household decreased from 0.7 to 0.5 (the average number of passenger cars in the household) in 2018 over 2011, while the average number of bicycles in the household increased from 1 to 1.2. The share of pedestrians in all journeys in the city increased from $19 \%$ 
in 2011 to as much as $24 \%$ in 2018. This growth was mainly at the expense of travel by public transport, which confirms the argument that it is public transport travellers who are the main group of potential PLEV users. The report on traffic in Wroclaw assumes an increase in the share of non-car transport in all journeys by Wroclaw residents to as much as $65 \%$ by 2020 [64]. Such growth assumptions provided a basis for the creation of a simulation model.

It should be noted that in the study we assumed the characteristics of mobility in Polish cities. When considering these issues for Asian cities or even southern Europe, the calculation of the effect of replacing motor scooters with e-motor scooters should be added. In Asian countries, motor scooters are the basis of urban mobility. In Poland (similarly in other countries of central, eastern and northern Europe) the phenomenon of motor scooters used in urban mobility practically has not occurred. It is only thanks to the introduction of the sharing systems that e-motor scooters began to be used in urban mobility with potential users among pedestrians who have so far covered some of their travels by walking or by public transport.

The behaviour of users being city dwellers is strongly dependent on market factors and legal solutions in the area of mobility. Market-related factors include fashion, beliefs, and subjective perception of consumers. Consumer behaviour can thus be influenced by promotional activities, including in particular advertising and sales promotion. Cities also resort to such measures as they try to influence the behaviour of their inhabitants through information campaigns and actions supporting or rewarding the desired behaviour of the city dwellers. The level of interest in electric mobility will therefore be influenced by the attitude of the cities towards this type of mobility. It seems that in the studies that are already available, researchers agree that PLEVs can help combat the nuisances currently faced by urban areas such as emissions, congestion, noise, and parking problems $[65,66]$. Asian cities have high hopes for e-motor scooters, and they see them as a rescue from omnipresent traditional scooters and motorcycles. Where scooters and motorcycles are responsible for the vast majority of traffic and, consequently, for the greatest air pollution caused by mobility, this is certainly a great hope for improvement, both in terms of reducing gas and particulate emissions, and noise [67].

The way energy is generated will also be of great importance for the impact of PLEVs on sustainable urban development. Such vehicles do not need much energy, but the demand for energy will also increase because their number will grow. Currently, Poland is one of the largest among the EU countries using hard coal for electricity production. According to the European Network of Transmission System Operators for Electricity (ENTSO-E) report of 16 December 2019, this raw material accounts for 43.5\% of all energy sources. Brown coal comes second with a share of 25.5\% [68]. Even though, that according to the Sandbag.org think tank analysis, in the first half of 2019 coal production in the EU has fallen by $19 \%$ on average, in Poland a reduction of only $6 \%$ was recorded. This was related to the launch of a new gas power plant in Płock.

As the e-motor scooter does not need much energy, it is easier to produce it in an unconventional way [69]. In this case, even domestic or private mini-wind or solar power plants can be considered. However, the general ecological balance of these e-vehicles seems to be a serious issue at the moment. Due to their short lifetime, they generate a lot of electro-waste in the form of worn-out batteries and entire devices [68].

Moreover, it seems the wind and solar installations are not being installed quickly enough in coal-bearing countries. In the major lignite-producing countries such as Poland, the Czech Republic, Romania, Bulgaria and Greece, it will not be possible to observe a decrease in production from this raw material unless they accelerate the implementation of wind and solar technologies. In addition, as electricity consumption begins to increase, including as a result of using electric cars, efforts to use renewable energy sources will need to be doubled in all countries.

It should be noted that the presented calculation of energy consumption did not take into account the impact of servicing on the total system energy balance. First of all, energy consumption (mainly fuel) associated with the servicing of e-motor scooters is not included, because at this stage of the study on this phenomenon there is no accurate data. For the calculation, it would be indispensable to 
know the length of routes travelled by service crews. It can be assumed that at this stage of system development the impact of service support on the total energy consumption of the system is not significant. The e-motor scooters used in this system have replaceable batteries. The e-motor scooters are used within a limited area concentrated around the city centre. Access to e-motor scooters for replacing batteries does not require overcoming long routes. Battery replacement is required less than once a day per one scooter. However, it should be taken into account in future calculations that for the scenario further system development, the impact of servicing on the energy balance of the entire system will increase.

As for the feelings of the users themselves, they vary. For the time being, the use of this innovative urban mobility method is at the level of early innovators [12]. Early innovators are a group that generally reaches for various unconventional solutions [50,70]. As a result, only brave enthusiasts reach for PLEVs. Concerns about the use of small electric vehicles include battery depletion, low vehicle speed, lack of adequate mobility infrastructure and safety. For some, these devices lose to a bicycle that is easier to manoeuvre, faster, and there are no concerns that the battery will run out [71]. However, a survey carried out in Munich has shown that the range of these vehicles and the infrastructure needed to recharge them are already sufficient to support daily mobility. On the other hand, the survey has indicated that the factors restricting such mobility are mainly the subjective feeling of insecurity, weather conditions, and the inability to carry luggage [65].

Several surveys, especially in the USA, have been devoted to accidents involving the users of PLEVs, mainly e-scooters. In all U.S. cities where the number of injuries (mainly head injuries) caused by accidents involving users of e-scooters was studied, a significant increase in these accidents and injuries was found [72-74]. Other studies concerning electric self-balanced scooters (solo-wheel and double-wheel) demonstrate that users of these mobility devices are not more likely to suffer head injuries than pedestrians. The authors argue that using these devices is no less safe than walking [13].

Mobility does not only depend on ever more technologically advanced devices, but also, and above all, on the behaviour of mobile urban users. Interference with habits and traditions of mobility is required in an attempt to change mobility from cars that are the most harmful to the environment and people to less polluting alternatives. Hence, the future fate of electric personal devices will depend not only on their technological usefulness, thus, charging time, battery life, availability, price, etc., but first of all on the extent to which and how fast (and whether permanently) these devices will be able to change the mobile mindset of the city dwellers [75].

With the increasing number of vehicles, a legal loophole and the need to regulate the presence of these devices in urban space have been noticed. In the U.S., for example, quite a serious discussion has been stirred up about the safety of these vehicles. There are many suggestions and recommendations concerning the introduction of the obligation to use helmets and protectors for these vehicles, as well as of regulations drastically limiting speed [76]. However, the policy on electric scooters in the U.S. varies. Cities are currently facing the problem of defining these mobility devices. Some states such as New Jersey and Massachusetts have practically banned their use. New Jersey has allowed their use only for people with specific disabilities, and Massachusetts has specified that only those vehicles/devices which have brake lights and indicators are permitted to operate in traffic [77]. The government in Poland has also published a new Highway Code, which made the PLEV equal to the bicycle and allowed it to use bicycle roads. The new Highway Code does not place any restriction on the PLEV but highly recommends helmet use [78].

\section{Conclusions}

To conclude, the average energy consumption per day per all e-motor scooters present on the market in Poland should be about 33.6 MWh. It means, that during a year, the cities will need 9.24 GWh to power their e-motor scooters. That is very significant amount compared to the example of Warsaw Metro energy consumption. 
Considering that a selection of Bass model parameters with limited data usually cause market value underestimation, another method of the estimation was adopted, namely forecasting by analogy (FBA). According to this approach, the most suitable model in this class would be the Bass model. It could be explained by the fact that the Bass model is a diffusion model with the most well-grounded interpretation. Moreover, the imitation and innovation parameters have a broader meaning in the context of Rogers interpretation. The estimation of the Bass model parameters for various technologies seems to be more common in the literature compared to the other representatives of this class (i.e., Gompertz or logistics models). In the absence of enough data for Poland, $\mathrm{p}$ and $\mathrm{q}$ parameters were selected based on carefully reviewed literature.

An attempt to estimate the parameters $p$ and $q$ is presented in the Appendix C. The estimation was made for a broader class of vehicles in the EU. The standard approach for estimating the parameters of the $\mathrm{p}, \mathrm{q}$ model and market size gave unsatisfactory results. The size of the target market was too small. Based on this experience, it was decided to estimate the market size for the EU (Appendix C) and for Poland (parameter $\mathrm{m}-$ main text). The consequence of this assumption would be an impact on the final value of the forecast. If models other than the Bass diffusion model are adopted, the growth rate would probably not change significantly.

If the growth rate is not high or the trend reverses, then with the current level of electricity consumption by PLEVs, the presence of e-motor scooters in cities will not have a significant influence on the amount of energy consumed.

However, if the growth scenario for cities continues, electric shared mobility will have a negative impact on the sustainable development of the city. It will necessitate a change in the approach to energy generation for Polish cities. In such case the alternative sources of obtaining electricity have to be considered.

The fact is that today the number of PLEVs in urban spaces is rising to such an extent that it requires specific regulatory steps. As things are, they comprise mainly transportation issues. However, as regards the simulation and the upward trend, regulatory action may as well be required in the area of electricity management. It may turn out that it is the political and legal factors that will ultimately determine the shape or even the future of this type of mobility.

Author Contributions: Conceptualization, A.B., G.C., J.J.; methodology, A.B., G.C., J.J.; software, A.B., G.C., J.J.; validation, A.B., G.C., J.J.; formal analysis, A.B., G.C., J.J.; investigation, A.B., G.C., J.J.; resources, A.B., G.C., J.J.; data curation, A.B., G.C., J.J.; writing—original draft preparation, A.B., G.C., J.J.; writing—review and editing, A.B.; visualization, A.B., G.C., J.J.; supervision, A.B.; project administration, A.B., G.C., J.J.; funding acquisition, $\mathrm{n} / \mathrm{a}$. All authors have read and agreed to the published version of the manuscript.

Funding: This research received no external funding.

Conflicts of Interest: The authors declare no conflict of interest.

\section{Appendix A}

According to the Bass model, the process of increment of innovation users can be defined by means of the following differential equation:

$$
\frac{d N(t)}{d t}=\left(p+\frac{q}{m} N(t)\right)(m-N(t))
$$

where:

$N(t)$ - the total number of innovation users at any given moment, so the derivative $N(t)$ over time represents an increment of new users;

$m$-the total number of potential and current innovation users, thus $(m-N(t))$ represents the number of potential innovation users. It is assumed in the Bass model that the whole market will adopt innovation. The market size must be known in order to use the Bass model;

$p$-the innovation coefficient reflecting the impact of the marketing activities of the innovation supplier on diffusion; 
$q$-the imitation coefficient, which is responsible for the replication of innovation by users.

Equation (A1) indicates that two components increase the number of users of a given innovation. The first one is $p[m-N(t)]$; the increment of users depends on the quality of marketing activities and the number of people who have not yet adopted innovation. The bigger the value of $p$, the more users will adopt innovation in a given moment (time period). Formally $p \in[0,1]$, but it usually does not exceed 0.05 .

The second component $q N(t) / m[m-N(t)]$ describes the part of the market that will adopt innovation under the influence of its current users. Product $q N(t) / m$ means the percentage share of innovation users, scaled by imitation coefficient $q$. The prerequisite for diffusion of innovation (market success) is a situation in which imitation coefficient $q$ will be higher than innovation coefficient $p$.

The analytical solution of the Bass model Equation (A1) is:

$$
N(t)=m \frac{(p+q)^{2}}{p} \frac{e^{-(p+q) t}}{\left(1+\frac{q}{p} e^{-(p+q) t}\right)^{2}} .
$$

The solution is described by a bell curve, similar in shape to normal distribution. A key parameter for the analysis of diffusion is the cumulative number of users. The function describing the total number of people and enterprises that have imitated innovation takes an S-shaped form. The solution of the Bass model Equation (A2) and the cumulative value of the users is therefore an analogy to the density of the normal distribution of probability and distribution function. In order to calculate the cumulative value, the integral from Equation (A2) must be calculated.

The Bass model is currently presented in a manner proposed by [79], where it is emphasized that in addition to parameters $p, q$ and $\mathrm{m}$, the starting point is also important. It means the moment when an innovation appeared on the market, and the time interval - the accuracy with which the model is calculated. Traditionally, most of the forecasts are presented on an annual basis, but if you want to present them on a monthly basis or on a different basis, you need to scale the parameters of the model accordingly. The authors propose k-relative position of the sales maximum point and an s-shape parameter instead of $\mathrm{p}$ and $q$ parameters, which formally shape the curve for Equation (A2).

\section{Appendix B}

For forecasting purposes, the key element is the selection of parameters $\mathrm{p}$ and $\mathrm{q}$ of the Bass model Equation (A1). In [54], based on the analysis of data containing over 1500 sets of $p$ and $q$, the parameter selection algorithm was proposed. In the algorithm, the forecaster must choose whether the product is durable, industrial, commercial, etc., and from which region it comes. For each profile a factor has been assigned. The algorithm sets a base coefficient that should be multiplied by these specified factors.

In case of innovation coefficient $p$, base line coefficient $p=0.016$ is multiply by 1.021 for each year after 1976, and by other regions coefficient 0.796 .

$$
\left\{\begin{array}{c}
p=0.016 \cdot 1.021^{2016-1976} \cdot 0.796=0.0292457 \\
q=0.409 \cdot 1.028^{2016-1976} \cdot 0.699=0.086283
\end{array}\right.
$$

Hower Bulte method gives also formal $90 \%$ confidence interval which is $p=(0.0040945 ; 0.210384)$ and $q=(0.310883 ; 5.7237)$. In the case of the parameter $q$, the factor formally takes the maximum value equal to 1 , therefore, the range of error can be considered much smaller than 5.7237 . It should be mentioned that the values of these errors were not included in the final forecast, due to the fact that most of the parameters $\mathrm{p}$ and $\mathrm{q}$ from the literature do not have error statistics assigned, which causes difficulties in comparison without additional assumptions. 


\section{Appendix C}

On the basis of data on the total number of alternative fuels from passenger cars [53] the coefficients of the Bass model were estimated using the least squares method. Calculations were performed using the Mathematica 11.3, the results with statistics are presented in Table A1.

Table A1. Estimated parameters p and q for Battery Electric Vehicle (BEV) and Plug-in Hybrid Electric Vehicle (PHEV) forecast in EU (exogenous potential $\mathrm{m}=3^{*} 10^{8}$ ) with standard error and $\mathrm{t}$-Statistic.

\begin{tabular}{ccccc}
\hline Coefficient & Estimate & Standard Error & t-Statistic & $p$-Value \\
\hline$p$ & 0.0000470316 & $9.46859 \times 10^{-6}$ & 4.96712 & 0.000423984 \\
$q$ & 0.333405 & 0.0267948 & 12.4429 & $8.00797 \times 10^{-8}$ \\
\hline
\end{tabular}

Available data present the early stage of development of a new technology, therefore the parameters determined are only a forecast, they do not describe the final development of innovation. Due to the fact that the estimation of $p$ and $q$ parameters using the least squares method usually underestimates the size of the market (as pointed out by many authors), therefore the size of the target market was arbitrarily set $m=3^{*} 10^{8}$ vehicles. In this context, attention should be paid to the comment in [48] regarding the division of forecasts without assumptions about the size of the market-endogenous potential and with the assumed size of the market-exogenous potential, because the forecasts differ significantly in both cases.

\section{Appendix D}

The authors of this paper would like to draw attention to a certain systemic problem with data analysis based on the Bass model. Obtaining the parameters $p$ and $q$ usually involves the use of various calculation procedures and making certain assumptions, not always clearly highlighted in the sources cited. Each assumption significantly affects the obtained result. In addition, there are issues of the correctness of the parameters available in the literature.

Table A2 below summarizes the same p and q parameters from different sources. Unfortunately, the parameters differ from the original ones. In the case of [48], there was a mistake in calculations and also a row change- the value 0.44632 comes from passenger vehicles and not from utility vehicles. The work [80] reproduced and quoted errors from [48]. In [44], there was a mistake that probably resulted from the assumption that these are annual, not monthly, parameters.

Table A2. The $p$ and $q$ parameters for arteriovenous fistula (AVF) utility from Shoemaker [49] presented in other sources (please note that these are the same coefficients).

\begin{tabular}{ccccc}
\hline Source & $p$ Monthly & $\boldsymbol{q}$ Monthly & $\boldsymbol{p}$ Yearly & $\boldsymbol{q}$ Yearly \\
\hline [49] Shoemaker (original) & 0.00776 & 0.0391 & $0.09312^{1}$ & $0.4692^{1}$ \\
[48]. Massiani and Gohs & $0.000677^{2}$ & $0.0386^{2}$ & 0.008124 & 0.4632 \\
[80] Wolken et al. & $0.000677^{2}$ & $0.0386^{2}$ & 0.008124 & 0.4632 \\
[44] Redondo and Cagigas & $0.000583^{2}$ & $0.0325^{2}$ & $0.007^{2}$ & 0.39 \\
\hline
\end{tabular}

${ }^{1}$ data were annualized by multiplication with factor $12 .{ }^{2}$ monthly data calculated on an annual basis (divided by 12).

The presented problem is the basis for a wider discussion. In fact, there is currently no way to verify the factors quoted from other sources, except for the reviewer's insight. There are no standards for securing calculations and copies of coefficients. Perhaps we should consider, in addition to the articles themselves, also presenting a certain file containing results in digital form. The above example is only intended to highlight the problem, because according to the [81] study, man has only $97 \%$ efficiency in copying data. 


\section{References}

1. UN Habitat, 2019. Available online: http://open.unhabitat.org/ (accessed on 14 July 2019).

2. IEA. World Energy Outlook 2010; International Energy Agency: Paris, France, 2010.

3. PricewaterhouseCoopers Report. The Sharing Economy: How is it Affecting You and Your Business? 2014. Available online: https:/pwc.blogs.com/files/sharing-economy-final_0814.pdf (accessed on 20 August 2019).

4. Light Electric Vehicle Association (LEVA). Available online: http://extraenergy.org/main.php?language=es \&category=information\&subcateg=99\&id=2285 (accessed on 16 August 2019).

5. Raport Transport Sharing w Polsce, 2019. Available online: https://www.dataart.com.pl/media/2827504/trans portsharing-2019.pdf (accessed on 17 August 2019).

6. Allegrini, J.; Orehounig, K.; Mavromatidis, G.; Ruesch, F.; Dorer, V.; Evins, R. A review of modelling approaches and tools for the simulation of district-scale energy systems. Renew. Sustain. Energy Rev. 2015, 52, 1391-1404. [CrossRef]

7. Bunn, D.W.; Gianfreda, A.; Kermer, S. A Trading-Based Evaluation of Density Forecasts in a Real-Time Electricity Market. Energies 2018, 11, 2658. [CrossRef]

8. Manfren, M.; Caputo, P.; Costa, G. Paradigm shift in urban energy systems through distributed generation. Appl. Energy 2011, 88, 1032-1048. [CrossRef]

9. Uniejewski, B.; Marcjasz, G.; Weron, R. On the importance of the long-term seasonal component in day-ahead electricity price forecasting. Part II—Probabilistic forecasting. Energy Econ. 2019, 79, 171-182. [CrossRef]

10. Hardt, C.; Bogenberger, K. Usability of eScooters in Urban Environments-A Pilot Study. In Proceedings of the Conference: 28th IEEE Intelligent Vehicles Symposium (IV), Redondo Beach, CA, USA, 11-14 June 2017; pp. 1650-1657.

11. Nocerino, R.; Colorni, A.; Lia, F.; Luè, A. E-Bikes and E-Scooters for Smart Logistics: Environmental and Economic Sustainability in Pro-E-Bike Italian Pilots. In Transportation Research Procedia, Proceedings of the Conference: 6th Transport Research Arena (TRA), Warsaw, Poland, 18-21 April 2016; Elsevier: Amsterdam, The Netherlands, 2016; pp. 2362-2371.

12. Seebauer, S. Why early adopters engage in interpersonal diffusion of technological innovations: An empirical study on electric bicycles and electric scooters. Transp. Res. Part A Policy Pr. 2015, 78, 146-160. [CrossRef]

13. Xu, J.; Shang, S.; Yu, G.; Qi, H.; Wang, Y.; Xu, S. Are electric self-balancing scooters safe in vehicle crash accidents? Accid. Anal. Prev. 2016, 87, 102-116. [CrossRef] [PubMed]

14. Chi, C.-F.; Chen, P.-L.; Saleh, W.; Tsai, S.-H.; Pai, C.-W. Helmet non-use by users of bikeshare programs, electric bicycles, racing bicycles, and personal bicycles: An observational study in Taipei. Int. J. Sustain. Transp. 2019, 13, 93-99. [CrossRef]

15. Santucci, M.; Pieve, M.; Pierini, M. Electric L-Category Vehicles for Smart Urban Mobility. In Transportation Research Procedia, Proceedings of the Conference: 6th Transport Research Arena (TRA), Warsaw, Poland, 18-21 April 2016; Elsevier: Amsterdam, The Netherlands, 2016; Volume 14, pp. 3651-3660.

16. Salmeron-Manzano, E.; Manzano-Agugliaro, F. The electric bicycle: Worldwide research trends. Energies 2018, 11, 1894. [CrossRef]

17. Bosetti, V.; Longden, T. Light duty vehicle transportation and global climate policy: The importance of electric drive vehicles. Energy Policy 2013, 58, 209-219. [CrossRef]

18. Morales Betancourt, R.; Galvis, B.; Rincón-Riveros, J.M.; Rodriguez-Valencia, A.; Sarmiento, O.L. Personal exposure to air pollutants in a Bus Rapid Transit System: Impact of fleet age and emission standard. Atmos. Environ. 2019, 202, 117-127. [CrossRef]

19. Canizes, B.; Soares, J.; Costa, A.; Pinto, T.; Lezama, F.; Novais, P.; Vale, Z. Electric Vehicles' User Charging Behaviour Simulator for a Smart City. Energies 2019, 12, 1470. [CrossRef]

20. Aymen, F.; Mahmoudi, C. A Novel Energy Optimization Approach for Electrical Vehicles in a Smart City. Energies 2019, 12, 929. [CrossRef]

21. Zhang, Y.; Aliya, B.; Zhou, Y.; You, I.; Zhang, X.; Pau, G.; Collotta, M. Shortest feasible paths with partial charging for battery-powered electric vehicles in smart cities. Pervasive Mob. Comput. 2018, 50, 82-93. [CrossRef]

22. Wang, Y.; Ding, W.; Huang, L.; Wei, Z.; Liu, H.; Stankovic, J.A. Toward Urban Electric Taxi Systems in Smart Cities: The Battery Swapping Challenge. IEEE Trans. Veh. Technol. 2018, 67, 1946-1960. [CrossRef] 
23. Shuai, W.; Maille, P.; Pelov, A. Charging Electric Vehicles in the Smart City: A Survey of Economy-Driven Approaches. IEEE Trans. Intell. Transp. Syst. 2016, 17, 2089-2106. [CrossRef]

24. Navarro, C.; Roca-Riu, M.; Furio, S.; Estrada, M. Designing New Models for Energy Efficiency in Urban Freight Transport for Smart Cities and Its Application to the Spanish Case. In Transportation Research Procedia, Proceedings of the 9th International Conference on City Logistics, Tenerife, Spain, 17-19 June 2015; Elsevier: Amsterdam, The Netherlands, 2016; Volume 12, pp. 314-324.

25. Chebbi, O.; Nouri, N. Reducing Energy Consumption in Smart Cities: A Scatter Search Based Approach. In Proceedings of the 2016 Genetic and Evolutionary Computation Conference (Gecco'16 Companion), Denver, CO, USA, 20-24 July 2016; pp. 1459-1460.

26. Hwang, J. Sustainable transport strategy for promoting zero-emission electric scooters in Taiwan. Renew. Sustain. Energy Rev. 2010, 14, 1390-1399. [CrossRef]

27. Hwang, J.; Chang, W. Life-cycle analysis of greenhouse gas emission and energy efficiency of hydrogen fuel cell scooters. Int. J. Hydrogen Energy 2010, 35, 11947-11956. [CrossRef]

28. Bishop, J.; Doucette, R.; Robinson, D.; Mills, B.; McCulloch, M. Investigating the technical, economic and environmental performance of electric vehicles in the real-world: A case study using electric scooters. J. Power Sources 2011, 196, 10094-10104. [CrossRef]

29. Walker, P.; Roser, H. Energy consumption and cost analysis of hybrid electric powertrain configurations for two wheelers. Appl. Energy 2015, 146, 279-287. [CrossRef]

30. OECD/Eurostat. Oslo Manual 2018: Guidelines for Collecting, Reporting and Using Data on Innovation. In The Measurement of Scientific, Technological and Innovation Activities, 4th ed.; OECD Publishing: Paris, France, 2018.

31. Lieswyn, J.; Fowler, M.; Koorey, G.; Wilke, A.; Crimp, S. Regulations and safety for electric bicycles and other low-powered vehicles. NZ Transp. Agency Res. Rep. 2017, 621, 182.

32. Dumaresq S (Segway Inc.). Segway Expands Launch of Its One s1-A Single Wheel, Electric, Self-Balancing Wonder-With Brick and Mortar Retail Rollout. News Release. 2017. Available online: https://www.busine sswire.com/news/home/20161205005148/en/Segway-Expands-Launch-S1---Single-Wheel (accessed on 24 August 2019).

33. Kot, S.M.; Karska, A.; Zając, K. Matematyczne Modele Procesów Dyfuzji Innowacji; Wydawnictwo Naukowe PWN: Warsaw, Poland, 1993; pp. 96-111.

34. Meade, N.; Islam, T. Modelling and forecasting the diffusion of innovation-A 25 year review. Int. J. Forecast. 2006, 22, 539-541. [CrossRef]

35. Bass, F. A new product growth model for consumer durables. Manag. Sci. 1969, 15, 215-227. [CrossRef]

36. Bauckhage, C.; Kersting, K. Strong Regularities in Growth and Decline of Popularity of Social Media Services. arXiv 2014, 11, 44.

37. Rogers, E.M. Diffusion of Innovations, 3rd ed.; Free Press of Glencoe: New York, NY, USA, 1983.

38. Hollister, S.; Holland, P.; Serrels, M.; Little, M. The Electric Scooter War Continues. Here's How They Work (FAQ). 31 May 2018. Available online: https://www.cnet.com/news/electric-scooters-bikes-dockless-ride-sh are-bird-lime-jump-spin-scoot/ (accessed on 24 August 2019).

39. Population Division. Annual Estimates of the Resident Population for Incorporated Places of 50,000 or More; U.S. Census Bureau: Suitland, MD, USA, 2018.

40. World Population Review, Population of All Cities in Poland 2019. Available online: http://worldpopulationr eview.com/countries/poland-population/cities/ (accessed on 24 August 2019).

41. Białek, J. Wieliczka. Elektryczne Hulajnogi są już w Mieście. Za Chwilę Pojawią się Także Skutery, 2019, September 8. Available online: https://dziennikpolski24.pl/wieliczka-elektryczne-hulajnogi-sa-juz-w-miesc ie-za-chwile-pojawia-sie-takze-skutery/ar/c1-14360509 (accessed on 24 August 2019).

42. Demographic Yearbook of Poland 2017; Central Statistics Office of Poland (GUS): Warsaw, Poland, 2018.

43. Area and Population in the Territorial Profile in 2018; Central Statistics Office of Poland (GUS): Warsaw, Poland, 2018.

44. Redondo, A.N.; Cagigas, A.P. Sales Forecast of Electric Vehicles. J. Eng. Arch. 2015, 3, 79-88. [CrossRef]

45. Wong, D.H.; Yap, K.B.; Turner, B.; Rexha, N. Predicting the Diffusion Pattern of Internet-Based Communication Applications Using Bass Model Parameter Estimates for Email. J. Internet Bus. 2011, 9, 38-41.

46. Wright, M.; Upritchard, C.; Lewis, T. A Validation of the Bass New Product Diffusion Model in New Zealand. Mark. Bull. 1997, 8, 28-29. 
47. Turk, T.; Trkman, P. Bass Model Estimates for Broadband Diffusion in European Countries. Technol. Forecast. Soc. Chang. 2011, 79, 85-96. [CrossRef]

48. Massiani, J.; Gohs, A. The choice of Bass model coefficients to forecast diffusion for innovative products: An empirical investigation for new automotive technologies. Res. Transp. Econ. 2015, 50, 17-28. [CrossRef]

49. Shoemaker, M.H. A Bass Diffusion Model Analysis: Understanding Alternative Fuel Vehicle Sales 2012. CMC Sr. Theses 2012, 399. Available online: http://scholarship.claremont.edu/cmc_theses/399 (accessed on 24 August 2019).

50. Kijek, A.; Kijek, T. Modelling of innovation diffusion. Oper. Res. Decis. 2010, 3-4, 53-68.

51. Sultan, F.; Farley, J.U.; Lehmann, D.R. A meta-analysis of diffusion models. J. Mark. Res. 1990, $27,70-77$. [CrossRef]

52. Jagodziński, J.; Ostrowski, D. Uzasadnienie potrzeby badań nad innowacyjnością w logistyce z wykorzystaniem modeli dyfuzyjnych. Zesz. Nauk. Wyższej Szkoły Bank. We Wrocławiu 2013, 37, 103-122.

53. Van den Bulte, C. Want to know how diffusion speed varies across countries and products? Try using a Bass model, Technical Report, PDMA VISIONS Making It Work. Glob. NPD 2002, 26, 12-15.

54. AF Fleet (Electricity) Total Number Alternative Fuels Passenger Cars; European Alternative Fuels Observatory: Brussel, Belgium, 2019.

55. Na Progu Przełomu, Report, Współdzielona Mobilność w Polsce 2019. Available online: http://mobilne-miasto .org/wp-content/uploads/2019/07/Raport_Shared_Mobility_2019_PL_maly.pdf (accessed on 24 August 2019).

56. Hollingsworth, J.; Copeland, B.; Johnson, J.X. Are e-scooters polluters? The environmental impacts of shared dockless electric scooters. Environ. Res. Lett. 2019, 14, 1-10. [CrossRef]

57. Confederation of the European Bicycle Industry (CONEBI). European Bicycle Market, 2015 Statistics, Industry\&Market Profile, 2016 ed.; CONEBI: Brussel, Belgium, 2016.

58. Confederation of the European Bicycle Industry (CONEBI). European Bicycle Market, 2016 Statistics, IndustryEMarket Profile, 2017 ed.; CONEBI: Brussel, Belgium, 2017.

59. Elektroroller Technische Forschung und Informationsdienste. Available online: http://www.elektroroller-ak tuell.com/electric-scooter-cost.html (accessed on 20 August 2019).

60. Metro Warszawskie Kupuje Energię na 2018 r. Available online: https://www.transport-publiczny.pl/wiado mosci/metro-warszawskie-kupuje-energie-na-2018-r-56010.html (accessed on 20 August 2019).

61. Nowa Miejska Mobilność. Co Oznacza Dla Ubezpieczeń? Available online: https://piu.org.pl/wp-content/up loads/2019/05/PIU-nowa-miejska-mobilnosc.pdf (accessed on 24 August 2019).

62. Mediolan Zapłaci Tym, Którzy Przesiądą Się Na Rower. Available online: http://www.miasto2077.pl/mediol an-zaplaci-ktorzy-przesiada-sie-na-rower/ (accessed on 29 August 2019).

63. Wykonanie kompleksowych badań ruchu we Wrocławiu i otoczeniu-KBR 2018 raport z realizacji etapu V. Pomiary liczby pasażerów w pojazdach komunikacji zbiorowej. Available online: http://bip.um.w roc.pl/artykul/565/37499/kompleksowe-badania-ruchu-we-wroclawiu-i-otoczeniu-kbr-2018 (accessed on 11 August 2019).

64. Kompleksowe Badania Ruchu We Wrocławiu i Otoczeniu 2018. Biuro Zrównoważonej Mobilności. Departament Infrastruktury $i$ Transportu. Available online: http://bip.um.wroc.pl/artykul/565/37499/kom pleksowe-badania-ruchu-we-wroclawiu-i-otoczeniu-kbr-2018 (accessed on 12 August 2019).

65. Hardt, C.; Bogenberger, K. Usage of e-scooters in Urban Environments. Transp. Res. Procedia 2019, 37, $155-162$. [CrossRef]

66. Hwang, J. Promotional policy for renewable energy development in Taiwan. Renew. Sustain. Energy Rev. 2010, 14, 1079-1087. [CrossRef]

67. Hsieh, P.Y.; Yu, T.Y.; Wu, K.C.; Chang, L.F.W. Influences and uncertainty of battery-swapping electric scooters on energy system in Taiwan. Energy Procedia 2018, 153, 95-100. [CrossRef]

68. ENTSO-E Releases Its Vision on Market Design and System Operation towards 2030. Available online: https://www.entsoe.eu/ (accessed on 17 December 2019).

69. Energetyka Odchodzi od Wẹgla. Available online: https://cleanerenergy.pl/2019/08/07/energetyka-odchodziod-wegla/ (accessed on 17 December 2019).

70. Moore, G.A. Marketing and Selling Disruptive Products to Mainstream Customers. In Crossing the Chasm, 3rd ed.; Harper Collins Publishers: New York, NY, USA, 2014. 
71. Statt, N. Report One Month with a Bird Rental Scooter: Far Worse Than A Bike. Bird's Monthly Program Sticks You with a Less Capable, More Annoying Scooter. The Verge. Available online: https://www.theverge .com/2019/7/31/20747817/bird-electric-scooter-monthly-rental-san-francisco-bike-app-review (accessed on 31 July 2019).

72. Badeau, A.; Carman, C.; Newman, M.; Steenblik, J.; Carlson, M.; Madsen, T. Emergency department visit for electric scooter-related injuries after introduction of an urban rental program. Am. J. Emerg. Med. 2019, 37, 1531-1533. [CrossRef]

73. Mayhew, L.; Bergin, C. Impact of e-scooter injuries on Emergency Department imaging. J. Med. Imaging Radiat. Oncol. 2019, 63, 461-466. [CrossRef]

74. Sikka, N.; Vila, C.; Stratton, M.; Ghassemi, M.; Pourmand, A. Sharing the sidewalk: A case of E-scooter related pedestrian injury. Am. J. Emerg. Med. 2019, 37, e5-e1807. [CrossRef]

75. Sopjani, S.; Janhager Stier, J.; Ritzén, S.; Hesselgren, M.; Georen, P. Involving users and users roles in the transition to sustainable moblity sytems: The case of light electric vehicle sharing in Sweden. Transp. Res. Part D Transp. Environ. 2019, 71, 207-222. [CrossRef]

76. Aizpuru, M.; Farley, K.X.; Rojas, J.C.; Crawford, R.S.; Moore, T.J., Jr.; Wagner, E.R. Motorized scooters injuries in the area of scooter-shares: A review of the national electronic surveillance system. Am. J. Emerg. Med. 2019, 37, 1133-1138. [CrossRef] [PubMed]

77. Pula, K.; Shinkle, D. Electric Scooters: Coming Soon to a Street, or Sidewalk, Near You; State Legislatures: Chicago, IL, USA, 2019; Volume 45, p. 2.

78. Kodeks Drogowy-Prawo o Ruchu Drogowym 2019. Available online: https://prawooruchudrogowym.pl/ (accessed on 4 October 2019).

79. Sokele, M.; Moutinho, L. Bass Model with Explanatory Parameters. In Innovative Research Methodologies in Management; Springer: Cham, Switzerland, 2018; pp. 145-164.

80. Wolken, A.; Smith, M.; Kaye-Blake, W.; Curry, K.; Dickson, M.; Drummond, C.; Thomas, A. Driving change: Technology diffusion in the transport sector. NZ Transp. Agency Res. Rep. 2018, 647, 130.

81. Gibson, W.H.; Megaw, E.D.; Young, M.S.; Lowe, E. A taxonomy of human communication errors and application to railway track maintenance. In Cognition Technology and Work; Springer: London, UK, 2005.

(C) 2020 by the authors. Licensee MDPI, Basel, Switzerland. This article is an open access article distributed under the terms and conditions of the Creative Commons Attribution (CC BY) license (http://creativecommons.org/licenses/by/4.0/). 